\title{
Driegeneraties- en tweeoudersvragen over het opleidingsniveau van mannen en vrouwen in Nederland
}

\author{
Maarten H.J. Wolbers \& Wout C. Ultee ${ }^{1}$
}

\section{Summary}

Three generations and two parents questions about the level of education of men and women in the Netherlands

This article estimates for the Netherlands linear regression models for an individual's level of education by bringing in parental as well as grandparental level of education. The prime question is that of the association between education in the first and third generation after holding constant education in the second generation. For the empirical analysis, we used the five available waves of the Family Survey Dutch Population as conducted in 1992-1993, 1998, 2000, 2003 and 2009. Since both primary respondents and their partner were interviewed about their father, mother and offspring, we could estimate statistical models in which the educational level of all grown-up children was regressed on the educational level of both parents and all four grandparents. The results show that grandfather's level of education has a direct effect on his grandchild's level of education, controlled for the educational level of one of the parents. In a model with both mother's and father's education, no longer a direct effect of grandfather's education is found. This suggests that the direct effect of grandfather's education has become indirect. Furthermore, the positive effect of grandfather's education on his grandchild's education declines as a function of parental education. In fact, only children with low educated parents profit from a high educated grandfather.

\section{Van vragen over beroepsklassen naar vragen over opleidingsniveau}

Voor Nederland en andere technologisch hoogontwikkelde landen is gebleken dat in de tweede helft van de twintigste eeuw het verband 
afnam tussen de beroepsklasse van ouders en die van hun kinderen (Breen \& Luijkx, 2004). Tevens daalde, over de gehele twintigste eeuw gerekend, de samenhang tussen de klasse waarin personen werden geboren en de opleiding die zij voltooiden (Breen et al., 2009). Dit onderzoek betreft evenwel verzorgingsstaten in hun ontstaanstijd, terwijl effecten van overheidsingrepen soms pas na lange tijd aan het licht komen. Sinds de komst van statelijke studiefinanciering bepalen de geldmiddelen van ouders, die sterk afhangen van hun beroepsklasse, niet meer de opleiding van hun kinderen. Ouders uit rijkere klassen beschikken echter over culturele hulpbronnen en die dragen zij nu meer over op hun kroost. Zo doen ze ten minste gedeeltelijk de geringere gevolgen teniet van materiële hulpbronnen. Deze compenserende strategie (Bourdieu, 1980: 177) zou leiden tot een sterkere samenhang tussen het opleidingspeil van ouders en kinderen. Hier gaan we in op de vraag naar de sterkte van dit verband.

Een andere reden voor de overdracht van meer culturele hulpbronnen en een sterker verband tussen de opleiding van ouders en kinderen vormt de kortere arbeidstijd, vastgelegd sinds de jaren zestig in de sociale wetten en collectieve arbeidsovereenkomsten van West-Europa. Die bepalingen verplichten tot een achturige werkdag, een vijfdaagse werkweek, zomers vrijaf en wettelijke pensionering. Tijdens doordeweekse avonden, in weekeinden en gedurende vakanties brengen ouders zodoende meer tijd met hun kinderen door, met alle gevolgen van dien. Hier komt bij dat, nu mensen door de vooruitgang in de geneeskunde ouder worden, de levens van personen en hun grootouders meer jaren samenvallen en deze generaties langer met elkaar omgaan. Daarom valt te voorzien dat grootouders hun culturele hulpbronnen meer gaan overdragen op hun kleinkinderen, met dezelfde gevolgen als de ouderlijke overdracht. Op die wijze zou de opleiding van personen sterker worden beïnvloed door die van hun grootouders. Om dit na te gaan, stellen we de driegeneratiestrendvraag.

Gezien deze verwachtingen is het gepast de aandacht te verleggen van de vraag in hoeverre landen als Nederland nog steeds klassensamenlevingen zijn (Goldthorpe, 1980; Breen, 2004), naar de minder terugblikkende en meer toekomstgerichte vraag in hoeverre deze landen steeds meer diplomamaatschappijen worden (Collins, 1981). Uit welke bijzondere vormen van vrijetijdsbesteding de overdracht van culturele hulpbronnen ook moge blijken, ouders bezitten meer culturele hulpbronnen als ze zelf een hoger diploma hebben (Halsey, Heath \& Ridge, 1980: 75). Vragen naar de samenhang tussen de opleidingsniveaus van leden van verschillende generaties zijn ook anderszins op zijn plaats. Gegevens over ouder-kindberoepsklassenmobiliteit bevatten niet alleen de neerslag van overdrachten van eerdere op latere generaties, maar ook van 
verschijnselen buiten gezin en familie, zoals langetermijnveranderingen in de beroepenstructuur van samenlevingen en schommelingen in hun werkloosheidspeil. Bij vragen over de trend in ouder-kindopleidingsmobiliteit heeft men minder te maken met zulke van het gezochte antwoord afleidende factoren.

\section{Vier fasen in het onderzoek naar twee of meer generaties en één of meer ouders}

Om het belang van onze vragen te benadrukken en om ze aan te kleden, schetsen we nu verschillen tussen vier fasen ${ }^{2}$ van onderzoek naar sociale stratificatie en mobiliteit. We doen dit niet alleen met als maatstaf de verzamelde gegevens en toegepaste statistische technieken (Treiman \& Ganzeboom, 2000), maar ook en vooral gezien de vigerende vragen. Er is wel gedaan alsof in de geschiedenis van het onderzoek naar sociale stratificatie en mobiliteit verkeerde vragen van het toneel verdwenen en de wel terechte vragen steeds verfijnder raakten (Ganzeboom, Treiman \& Ultee, 1991). Wanneer de geschiedenis van dit onderzoek minder uit het heden wordt geschreven, blijkt echter dat in de eerste fase vragen over wie met wie trouwt en vragen over grootouders ter sprake kwamen, evenals vragen over moeders en dochters en vragen over beroepsloopbanen. Deze andere vragen stonden evenwel in de eerste fase en in latere fasen in de schaduw van vragen over vader-zoonmobiliteit. We vangen deze vervaging in het beeld van de openheid van hedendaagse samenlevingen op met vragen voor de opleiding van mannen en die van vrouwen, die de opleiding van vaders en moeders en alle vier de grootouders in de beschouwing betrekken. Zo breiden we aloude vragen over twee generaties mannen uit tot driegeneraties- en tweeoudersvragen voor beide geslachten.

Een terugblik op de eerste onderzoeken met steekproeven en vragenlijsten naar maatschappelijkge gelaagdheid in de Westerse wereld (Glass, 1954; Svalastoga, 1959; Van Tulder, 1962) leert dat ze bepaald verder reikten dan de vaststelling van de tegenwoordig in de sociologie zoveel aandacht trekkende sterkte van het verband tussen het beroep van vaders en zonen (Ultee, Arts \& Flap, 2003: H. 24). Deze studies, waarvoor de gegevens kort na de Tweede Wereldoorlog werden verzameld, stelden stijging en daling op de maatschappelijke ladder tussen twee generaties vast. Het onderzoek van Glass (1954) en zijn kring omvatte de steekproef van volwassen mannen en vrouwen in Engeland, Schotland en Wales in 1948 en alom bekend werd de tabel waarin de beroepsklasse van mannen was afgezet tegen die van hun vader. Dergelijke vader-zoontabellen kwamen er ook voor andere landen. Hun vergelijking (Lipset \& Bendix, 1959) vormt de bekroning van de eerste fase van mobiliteitsonderzoek. 
Het onderzoek van de eerste fase wilde ook de mate verklaren waarin personen op de maatschappelijke ladder stijgen of dalen. Daartoe trokken ze de huidige beroepshoogte van mannen af van dat van hun vader en deze score zetten ze af tegen onder meer hun niveau van opleiding (Van Tulder, 1962: 191). Deze verschilscores leidden echter tot onheilzame vloer- en plafondeffecten in de resultaten: iemand die aan de top begint zal nooit stijgen; een onderaan aanvangend persoon kan niet nog verder omlaag. Duncan wees op die kwestie (Blau \& Duncan, 1967: 194199), daarmee het startschot gevend voor een tweede fase in het mobiliteitsonderzoek. Hij verving de vraag welke factoren iemands mate van stijging of daling verklaren, door de betere vraag in welke mate herkomst effect heeft op bestemming. Tevens stelde hij de vraag in welke mate andere factoren, zoals opleiding, dat doen. Verder wilde hij weten in hoeverre het effect van vaders beroep op dat van zijn zoon rechtstreeks is en hoeverre het loopt via de opleiding van de zoon. De sterkte van totale, directe en indirecte effecten las Duncan af aan de grootte van lineaire regressiecoëfficiënten.

Duncan mat beroepshoogte met een intervalschaal. Tijdens de eerste fase in het mobiliteitsonderzoek deed men dat evenwel met een lijstje van enkele beroepsklassen. Lineaire regressiecoëfficiënten komen dan niet van pas. Goldthorpe (1980) achtte bovendien de vraag naar de samenhang tussen het beroep van vaders en zonen te grof: beroepen kunnen verschillen in de mate waarin ze van de ene op de andere generatie worden overgedragen. Uit lineaire regressiemodellen kan zoiets niet blijken; wel uit odds ratio's en op deze maten stoelende loglineaire modellen. Deze modellen, en de bijbehorende meer verfijnde vragen over mobiliteit tussen combinaties van bepaalde klassen, zijn kenmerkend voor de derde fase in het mobiliteitsonderzoek. De toonaangevende onderzoeken voor de Verenigde Staten in 1973 (Featherman \& Hauser, 1978) en voor Engeland en Wales in 1972 (Goldthorpe, 1980), bevatten odds ratio's. Hier berekenen we enige odds ratio's en schatten we vooral lineaire regressiemodellen. We beschouwen de schaal voor opleiding als een intervalschaal en gaan er vooralsnog van uit dat één jaar meer opleiding steeds hetzelfde effect heeft, of dat nu een jaar aan de onder- of aan de bovenkant van de schaal betreft.

Vader-zoonberoepsmobiliteit is echter slechts één vorm waarin de openheid van sociale structuren zich voordoet, en het onderzoek uit de eerste fase behelsde vier andere aanwijzingen daarvoor. We laten die nu de revue passeren. Om te beginnen bestudeerde Berent (1954) uit de kring rond Glass trouwpatronen. Met de gegevens van Glass bepaalde hij het verband tussen de herkomst van mannen en die van hun echtgenote en tevens het verband tussen de opleiding van de twee echtelieden zelf. In de tweede fase kwam eveneens de vraag wie met wie trouwt aan bod. 
Zo stelde Duncan met gegevens uit 1962 voor geboortecohorten in de Verenigde Staten veranderingen vast in de samenhang tussen het aantal jaren opleiding van huwelijkspartners. Dat deed hij met Pearson correlatiecoëfficiënten (Blau \& Duncan, 1967: 354-359). Deze maat was op de plaats, omdat opleiding gemeten als het aantal jaren met goed gevolg afgesloten onderwijs, een intervalschaal vormt. De derde fase kent een vergelijking van op odds ratio's berustende maten voor trouwen naar opleiding in 23 technologisch hoogontwikkelde samenlevingen in de jaren tachtig (Ultee \& Luijkx, 1990). Die maten werden uitgerekend omdat de schaal voor opleidingshoogte, hoewel deze betrekking had op het aantal jaren met goed gevolg doorlopen onderwijs, maar vier categorieën omvatte, wat de berekening van correlatiecoëfficiënten op losse schroeven zet. In dit artikel beantwoorden we, bijna in het voorbijgaan, de vraag in hoeverre een persoon een hoger opgeleide wederhelft heeft indien de eigen én de vaderlijke opleiding hoger is.

Naast de vraag wie met wie trouwt, maakte de vraag in hoeverre het beroep van individuen niet alleen afhangt van dat van hun vader, maar ook van dat van hun vaders vader, deel uit van de eerste fase van stratificatieonderzoek. Als grootvaders een eigen invloed hebben, is er sprake van meer geslotenheid. Svalastoga (1959) verzamelde gegevens over drie generaties in Denemarken in 1953. Mukherjee (1954) van de kring rond Glass bewerkte de data over drie generaties voor Groot-Brittannië in 1948. In beide studies blijft het voor een hedendaagse lezer echter onduidelijk in hoeverre personen, onafhankelijk van het beroep van hun vader, hoger op de sociale ladder staan indien hun grootvader ook een hoger beroep had. Dit komt, behalve door de berekening van misleidende verschilscores, door de onbekendheid destijds met tabeluitsplitsing en multipele regressie. In dit artikel pakken we de draad van driegeneratiesvragen op door deze vormen van multivariate analyse toe te passen.

Hoewel in de eerste fase van mobiliteitsonderzoek Glass en Svalastoga gegevens onder vrouwen verzamelden, wisten ze met de analyse van deze gegevens niet goed raad. Te weinig vrouwen oefenden een beroep uit en hetzelfde gold voor hun moeder om vader-zoon met moeder-dochterberoepsmobiliteit te vergelijken. De steekproef van het boegbeeld van de tweede generatie (Blau \& Duncan, 1967) betrof alleen mannen (hoewel er gegevens over hun wederhelft werden verzameld). Hetzelfde geldt voor de opvolger voor de Verenigde Staten in 1973 (Featherman \& Hauser, 1978) en voor de steekproef voor Engeland en Wales in 1972 (Goldthorpe, 1980). Voor het toonbeeld van de vierde fase van stratificatieonderzoek, de gegevens vergaard in West-Duitsland in 1981-1983 voor cohorten geboren in 1929-1931, 1939-1941 en 1949-1951, werden wel mannen en vrouwen ondervraagd. Voor beide geslachten werd de gehele beroepsloopbaan, met inbegrip van de levensfasen waarin mensen geen 
betaalde arbeid uitoefenden, vastgelegd (Blossfeld \& Mayer, 1988). Wat antwoorden op vragen over vrouwen betreft, ging een onderzoek uit de derde fase voor Engeland en Wales in 1972 het verst: het opleidingspeil van moeders leidde, onafhankelijk van de beroepsklasse van vaders, tot meer opleiding bij hun zonen (Halsey, Heath \& Ridge, 1980). Daarmee werd Duncans vadermodel verbreed tot een tweeoudersmodel. Hier schatten we naast tweeoudersmodellen ook viergrootoudersmodellen, wat we voor mannen en vrouwen afzonderlijk doen. Omdat onze vragen over de opleiding van personen gaan, hebben we niet te maken met de kwestie wat te doen als grootmoeders, moeders of dochters geen beroep uitoefen(d)en.

De studies van de eerste onderzoeksfase schetsten ten slotte de opof neergaande lijn tijdens het beroepsleven van een persoon. Dit is het onderscheid tussen intergenerationele en intragenerationele mobiliteit, dat Sorokin maakte in een beschouwende studie uit 1927, en net als meer intergenerationele stijging duidt meer intragenerationele stijging erop dat de sociale structuur van samenlevingen opener is. Svalastoga (1959) tekende de op- of neergaande lijn van beroepsloopbanen in Denemarken in 1953 uit met de gemiddelde status van zowel mannen als vrouwen toen ze $20,30,40,50,60,70$ en 80 jaar oud waren. Het zou tot de vierde fase duren voor gegevens over beroepsloopbanen zo werden gemodelleerd dat ze antwoord gaven op vragen waaraan geen gebreken kleven (Blossfeld \& Mayer, 1988). De vraag hoeveel mobiliteit zich in een land op een bepaald tijdstip voordoet, is namelijk verkeerd. Mobiliteit voltrekt zich altijd tussen twee tijdstippen en de afstand daartussen dient voor alle onderzochte leden van een samenleving gelijk te zijn om de simpele reden dat in een langer tijdsbestek meer zal gebeuren. Deze gelijkheid geldt echter niet voor de eerste, tweede en derde fase van het mobiliteitsonderzoek. In deze fasen kruiste men de huidige beroepsklasse van elk op een tijdstip in een land werkend persoon tegen de beroepsklasse van hun vader in hun jeugd. Aan de in de vierde fase toegepaste modellen ter analyse van gebeurtenissen in bepaalde even lange periodes gaan we hier evenwel voorbij. Omdat de opleiding van volwassenen, zowel (groot) ouders als hun (klein)kinderen, bijna zonder uitzondering gelijk blijft tijdens het leven, kan de vierde fase bij vragen over intergenerationele opleidingsmobiliteit passend worden overgeslagen. In dit artikel stellen we, voor gegevens verzameld in Nederland in de periode 1992-2009, vragen over de plaats op de maatschappelijke ladder van zowel mannen als vrouwen. De Nederlandse dataverzameling was geënt op de genoemde voor Duitsland (Blossfeld \& Mayer, 1988). 


\section{Hypothesen, hun toetsing tot nu toe, alternatieve hypothesen}

$\mathrm{Al}$ in de beschouwende literatuur voorafgaand aan de eerste fase van mobiliteitsonderzoek treffen we hypothesen aan over de mate van standvastigheid van sociale posities over meer dan twee generaties. Zo wees Schumpeter (1927: 129) op het Amerikaanse gezegde 'in drie generaties van overall naar overall'. In de eerste fase van het onderzoek voegde Lipset daar gezegden voor andere landen aan toe, te weten 'de derde kritische generatie' voor Duitsland, 'van klompen tot klompen in drie generaties' voor Engeland en 'een familie kan van lompen tot rijkdom gaan in drie generaties en in de volgende drie weer terug naar lompen' voor China (Lipset \& Bendix, 1959: 74). Achter deze spreekwoorden staat klaarblijkelijk de hypothese dat sociale daling volgt op sociale stijging. Mag daaruit de gevolgtrekking worden gemaakt dat na daling stijging komt? Vermeden moet echter worden dat met verschilscores wordt gewerkt, wat deze hypothesen doen. De betere hypothese luidt dat iemand met ouders en grootouders in een hoger milieu een grotere kans heeft op een hogere positie dan iemand van wie de ouders tot een hoger milieu behoren en de grootouders tot een lager.

Een bivariate samenhang tussen de hoogte van een individu op de maatschappelijke ladder en die van de grootouders van deze persoon verschaft vanzelfsprekend een zwakke toetsing van de hypothese dat het hebben van een grootvader met zo'n plaats de positie van deze persoon veroorzaakt. Dat komt omdat een alternatieve hypothese ter verklaring van dit verband voor de hand ligt: grootouders met een hogere positie hebben kinderen die daarom hoger terecht komen, en die kinderen bewerkstelligen op hun beurt dat het hun kroost goed gaat. Grootouders hebben niet directe gevolgen voor hun kleinkinderen, maar indirecte.

Het is ook niet altijd inzichtelijk waarom grootouders een direct effect op hun kleinkinderen zouden hebben. Vaders met een eigen bedrijf kunnen hun zonen in dat bedrijf laten beginnen en die kunnen dat overnemen bij de dood van hun vader. Een dergelijke overdracht is echter moeilijk voorstelbaar als het om grootvaders en hun kleinkinderen gaat. Ook als het niet om het erven van een onderneming gaat, maar om het inzetten van geldmiddelen, dan wordt een effect zonder tussenkomst van de ouderlijke geldmiddelen bepaald gezocht.

Toch valt, zoals we eerder betoogden, een direct grootouderlijk effect te verwachten, terwijl ook een sterker effect voor latere dan voor eerdere geboortecohorten is te voorzien. Onze hypothese betreft echter niet de invloed van beroepshoogte, maar van opleidingsniveau: gevolgen van grootouders voor hun kleinkinderen treden zonder tussenkomst van hun kinderen op indien grootouders culturele hulpbronnen inzetten. Daarvoor is ook meer gelegenheid in het huidige Nederland: grootou- 
ders en kleinkinderen trekken meer met elkaar op door de toename van vrije tijd en door de hogere levensverwachting. Een recente Britse studie ter beantwoording van driegeneratiesvragen over beroepsklassen, vindt een grootouderlijk effect zonder tussenkomst van de middengeneratie en zoekt daarvoor een verklaring bij de ongelijke beschikking over culturele hulpbronnen (Chan \& Boliver, 2013).

De vraag is natuurlijk welke grootouders effect hebben. Als in Nederland vandaag de dag scholen en bedrijven nog steeds mannenbolwerken zijn, zullen de effecten van grootvaders opleiding die van grootmoeders opleiding overtreffen. En als in Nederlandse gezinnen mannen nog steeds aan het hoofd van het huishouden staan, zullen de effecten van vaders vader die van moeders vader overtreffen. Zoals deze voorwaardelijke formuleringen aangeven, vallen hier in de loop van de tijd veranderingen te verwachten in de richting van minder ongelijke effecten. We laten open in hoeverre deze inmiddels tot volle rijpdom zijn gekomen. Het is algemeen bekend dat een steeds hoger percentage vrouwen werkt en binnen paren huishoudelijke taken minder op de schouders van vrouwen rusten.

Als gezinnen patriarchaal zijn en scholen en bedrijven door mannen worden gedomineerd, valt ook te voorspellen dat het effect van moeders opleiding op de opleiding van hun kinderen kleiner is dan het effect van vaders opleiding. Gezien de algemene maatschappelijke veranderingen vallen ook hier minder ongelijke effecten te verwachten. Maar ook kunnen de gevolgen van moeders opleiding voor die van hun kinderen afnemen. Immers, werkende moeders hebben minder mogelijkheden om culturele hulpbronnen over te dragen.

Naast de hypothese dat hoger opgeleide grootouders rechtstreeks een hogere opleiding bij hun kleinkinderen bewerkstelligen, plaatsen we hier twee hypothesen, die tezamen een alternatief vormen. Volgens de ene leidt, behalve de hogere opleiding van vaders, ook de hogere opleiding van moeders tot hoger opgeleide kinderen. Volgens de andere hypothese hangt het opleidingsniveau van grootvaders en hun zonen samen en heeft een hogere opleiding van grootvaders als gevolg dat hun zonen een vrouw met een hogere opleiding huwen. Deze hypothesen brengen met zich mee dat een rechtstreeks lijkend gevolg van grootvaders opleiding op de opleiding van hun kleinkind (in een model zonder de opleiding van de moeder) tot stand kan zijn gekomen langs de omweg van de hogere opleiding van hun moeder. Voor Nederland is gevonden dat hoger opgeleide personen met een grotere kans een hoger opgeleid persoon te huwen, evenals dat een persoon dit doet, onafhankelijk van de eigen opleiding, als de vader van deze persoon hoog is opgeleid (De Graaf et al., 2003). Daarom schatten we hier modellen voor drie generaties en twee ouders tegelijk. 
Mare (2011) heeft beredeneerd dat, hoewel voor de staat Wisconsin in de Verenigde Staten voor een cohort dat in 1957 de middelbare school verliet, geen direct effect is gevonden van het grootouderlijk milieu, de gehanteerde analysetechnieken te grof kunnen zijn geweest om dit te vinden. Hij houdt staande dat Duncans tweegeneratiesmodellen toepasbaar zijn op het brede maatschappelijk midden, maar niet op een eng omschreven topgroep, waarbij hij aan de superrijken lijkt te denken (Lundberg, 1968), en op de na de afschaffing van de slavernij ontstane grootstedelijke onderklasse (Jencks \& Peterson, 1991). Deze hypothese komt er ons inziens niet alleen op neer dat naast ouderlijke hoogte op de maatschappelijke ladder grootouderlijke opleidingshoogte gevolgen heeft, maar ook dat de combinatie van beide kenmerken een effect heeft. We schatten daarom tevens modellen met een interactieterm tussen de opleiding van de grootouders en de ouders. Aangezien Nederland veel minder dan de Verenigde Staten een land is met superrijken, maar wel een onderklasse kent (Engbersen, 1990), voorspellen we hier een negatieve interactie tussen de opleiding van de grootouders en de ouders.

\section{Onderzoeksopzet}

We analyseren gegevens van de Familie-enquête Nederlandse Bevolking (FNB), een periodiek herhaalde, grootschalige persoonsenquête die retrospectieve data bevat over de volledige opleidings- en beroepsloopbaan van zowel primaire respondenten als hun partner. Het onderzoek is eind vorige eeuw opgezet door de sectie Sociologie van de Radboud Universiteit Nijmegen. Tot nu toe werden er vijf keer gegevens verzameld, te weten in 1992-1993, 1998, 2000, 2003 en 2009 (Ultee \& Ganzeboom, 1993; De Graaf et al., 1998, 2000, 2003; Kraaykamp, Ruiter \& Wolbers, 2009). De respons lag telkens rond de $45 \%$. Omdat de interviews meer dan een uur duurden en primaire respondenten en hun partner beiden zijn ondervraagd, kan deze respons als relatief hoog worden beschouwd. Bij de primaire respondent is eerst een mondeling interview afgenomen, waarna deze vervolgens een schriftelijke vragenlijst invulde; bij de partner van de primaire respondent was dit andersom. Elke respondent is naar de opleiding en het beroep van hun vader en moeder gevraagd, evenals naar dat van al hun (volwassen) kinderen. Bovendien is een schriftelijke vragenlijst gestuurd naar een van de ouders van de primaire respondent en hun partner (als deze ouder nog in leven was) en naar een willekeurig kind (indien er één minstens 25 jaar was). Voor elk meetjaar vormden de primaire respondenten een aselecte steekproef uit de Nederlandse populatie tussen de 18 en 70 jaar. Individuen die gehuwd of ongehuwd samenwoonden met een partner werden bewust oververtegenwoordigd. Dat de steekproef op dit punt niet representatief is, beschouwen we als een voordeel voor de vraagstelling van dit artikel. ${ }^{3}$ 
In de geschatte multipele lineaire regressiemodellen zijn de ouders (tweede generatie) onze primaire respondenten en hun partner; de grootouders (eerste generatie) zijn de ouders van de primaire respondenten en van hun partner, en de individuen van wie het opleidingsniveau wordt verklaard (derde generatie) zijn de kinderen van de primaire respondenten en hun partner. ${ }^{4}$ Omdat zowel primaire respondenten als hun partner zijn ondervraagd over hun vader en moeder, zijn we in staat regressiemodellen te schatten met de opleiding van alle vier de grootouders. En omdat primaire respondenten en hun partner in het algemeen meer dan een kind met voltooid onderwijs hebben, kunnen ze meer dan een keer in de dataset voorkomen. Om die reden presenteren we regressiemodellen met geclusterde standaardfouten op kindniveau. In totaal analyseren we 2400 (volwassen) kinderen (van 25 jaar en ouder). Het betreft 1253 mannen en 1147 vrouwen. Leden van het oudste cohort zijn geboren in de periode 1940-1969; dit cohort bestaat uit 1208 individuen. Het jongste geboortecohort verwijst naar de periode 1970-1984 en bevat 1192 respondenten. We hebben alle respondenten verwijderd met ontbrekende waarden op één of meer van de geanalyseerde variabelen. Deze ontbrekende waarden hebben betrekking op de opleidingsvariabelen, maar komen zeer weinig voor. De opleiding van de ouders is slechts in $0,1 \%$ van de gevallen onbekend, de opleiding van de kinderen in $0,9 \%$ van de gevallen en die van de grootouders in maximaal 3,9\% van de gevallen (voor moeders vader). We verwachten daarom geen vertekening in de uitkomsten op dit punt.

De gehanteerde opleidingsindeling verwijst naar de hoogst behaalde opleiding (van kinderen, ouders en grootouders) en bestaat uit de volgende tien niveaus:

1. lagere school, basisschool, vglo [6 jaar];

2. lbo, huishoudschool, vbo, vmbo (kader of beroepsgerichte leerweg) [10 jaar];

3. mavo, ulo, mulo, vmbo (theoretische of gemengde leerweg) [10 jaar];

4. havo, mms [11 jaar];

5. vwo, hbs, atheneum, gymnasium [12 jaar];

6. kort mbo, primair leerlingwezen [12 jaar];

7. tussen/lang mbo, secundair/tertiair leerlingwezen [14 jaar];

8. hbo, kandidaatsexamen, bachelorexamen [17 jaar];

9. universiteit, doctoraalexamen, masterexamen [19 jaar];

10. postacademisch (bijv. notariaat, doctorstitel, artsexamen) [22 jaar].

Tussen vierkante haken vermelden we het aantal jaren onderwijs dat door de bank genomen staat voor deze niveaus. In de lineaire regressiemodellen wordt het aantal jaren onderwijs van een individu afhankelijk gesteld van het aantal jaren onderwijs van zijn of haar ouders en groot- 


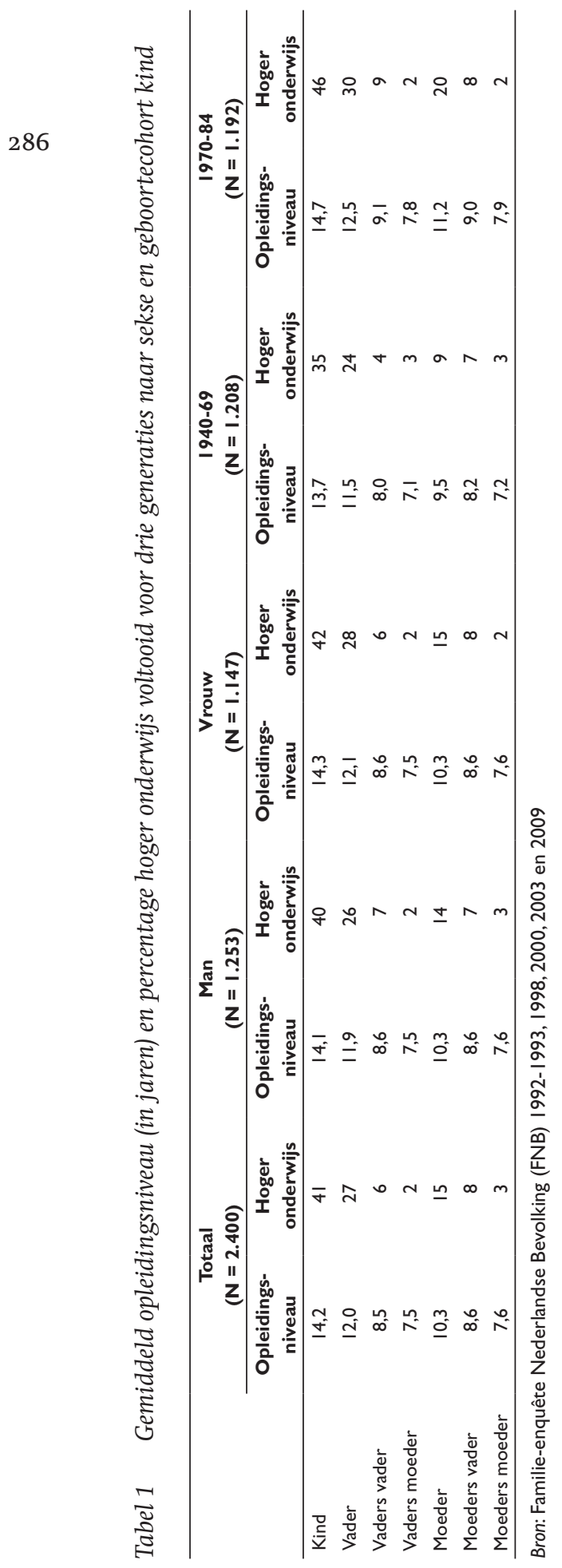


ouders. In de beschrijvende tabellen onderscheiden we tussen het al dan niet hebben voltooid van hoger onderwijs (hbo of hoger tegenover lager).

Tabel 1 toont het gemiddelde opleidingsniveau (in jaren) voor de eerste, tweede en derde generatie. Daarbij wordt onderscheiden tussen

de twee hierboven omschreven geboortecohorten en beide geslachten. Tevens wordt vermeld het percentage dat hoger onderwijs voltooide. De resultaten laten zien dat de derde generatie, zowel bij mannen als vrouwen, hoger is opgeleid dan de tweede en de tweede hoger dan de eerste. Daarnaast komt naar voren dat het opleidingsniveau van individuen geboren tussen 1970 en 1984 hoger is dan voor degenen van het geboortecohort 1940-1969. Verder geldt dat de vaders van kinderen uit het latere cohort over een hoger opleidingsniveau beschikken; hetzelfde is het geval voor de moeders. Dit patroon valt, ten slotte, ook te ontdekken wanneer de opleiding van vaders vader, vaders moeder, moeders vader en moeders moeder wordt vergeleken.

\section{Tabeluitsplitsingen}

In tabel 2a is het opleidingsniveau van het kind (derde generatie) afgezet tegen dat van hun ouders (tweede generatie). De niveaus zijn teruggebracht tot het onderscheid tussen wel of geen hoger onderwijs. Wanneer we de derde generatie zowel met hun moeders als hun vaders vergelijken, dan blijkt in beide gevallen de odds ratio ongeveer vijf te zijn. Als we het aantal jaren onderwijs voor de tweede en derde generatie met elkaar in verband brengen, dan bedraagt de correlatiecoëfficiënt respectievelijk 0,35 en 0,39 . Op basis van tabel $2 \mathrm{~b}$ kunnen we concluderen dat de odds ratio voor de samenhang tussen het opleidingsniveau van de grootouders (eerste generatie) en ouders hoger is (10 of meer). Hetzelfde geldt voor de correlatiecoëfficiënt, die minimaal 0,40 bedraagt. Tabel 2c laat zien dat er ook een bivariate samenhang is tussen het opleidingsniveau van de eerste en derde generatie. Deze samenhang, zowel uitgedrukt in een odds ratio als correlatiecoëfficiënt, is echter lager dan bij vergelijking van het opleidingsniveau van de tweede en derde generatie en die van de eerste en tweede.

De belangrijkste vraag is natuurlijk of de positieve samenhang tussen het opleidingsniveau van de eerste en derde generatie blijft bestaan als we rekening houden met het opleidingsniveau van de tweede. Tabel 3 geeft het antwoord op deze vraag. Het blijkt dat indien de ouders geen hoger onderwijs voltooiden, er een samenhang is tussen het opleidingsniveau van de grootvader en het kleinkind. In het geval van vaders opleiding is de odds ratio 2,08; in het geval van moeders opleiding 1,61. De partiële correlatiecoëfficiënt tussen de eerste en derde generatie, gecontroleerd voor de tweede, bedraagt respectievelijk 0,06 en 0,07. Als de 
Tabel $2 a \quad$ Samenhang tussen opleiding ouders en kind (rijpercentages)

\begin{tabular}{|c|c|c|c|}
\hline & & \multicolumn{2}{|c|}{ Kind } \\
\hline & & Geen hoger onderwijs & Hoger onderwijs \\
\hline \multirow[t]{2}{*}{ Vader } & Geen hoger onderwijs & 70 & 30 \\
\hline & Hoger onderwijs & 30 & 70 \\
\hline \multicolumn{4}{|c|}{ Odds ratio: 5,43} \\
\hline \multicolumn{4}{|c|}{ Correlatie (opleidingsniveau): 0,39 } \\
\hline & & \multicolumn{2}{|c|}{ Kind } \\
\hline & & Geen hoger onderwijs & Hoger onderwijs \\
\hline \multirow[t]{2}{*}{ Moeder } & Geen hoger onderwijs & 65 & 35 \\
\hline & Hoger onderwijs & 29 & 71 \\
\hline \multicolumn{4}{|c|}{ Odds ratio: 4.47} \\
\hline \multicolumn{4}{|c|}{ Correlatie (opleidingsniveau): 0,35} \\
\hline
\end{tabular}

Bron: Familie-enquête Nederlandse Bevolking (FNB) 1992-1993, 1998, 2000, 2003 en 2009

Tabel $2 b \quad$ Samenhang tussen opleiding grootouders en ouders (rijpercentages)

\begin{tabular}{|c|c|c|c|}
\hline & & \multicolumn{2}{|c|}{ Vader } \\
\hline & & Geen hoger onderwijs & Hoger onderwijs \\
\hline \multirow[t]{2}{*}{ Vaders vader } & Geen hoger onderwijs & 77 & 23 \\
\hline & Hoger onderwijs & 19 & 81 \\
\hline \multicolumn{4}{|c|}{ Odds ratio: 13,86} \\
\hline \multicolumn{4}{|c|}{ Correlatie (opleidingsniveau): 0,40} \\
\hline & & \multicolumn{2}{|c|}{ Moeder } \\
\hline & & Geen hoger onderwijs & Hoger onderwijs \\
\hline \multirow[t]{2}{*}{ Moeders vader } & Geen hoger onderwijs & 89 & 11 \\
\hline & Hoger onderwijs & 45 & 55 \\
\hline \multicolumn{4}{|l|}{ Odds ratio: 9,96} \\
\hline \multicolumn{4}{|c|}{ Correlatie (opleidingsniveau): 0,42} \\
\hline
\end{tabular}

Bron: Familie-enquête Nederlandse Bevolking (FNB) 1992-1993, 1998, 2000, 2003 en 2009

Tabel 2c Samenhang tussen opleiding grootouders en kind (rijpercentages)

\begin{tabular}{|c|c|c|c|}
\hline & & \multicolumn{2}{|c|}{ Kind } \\
\hline & & Geen hoger onderwijs & Hoger onderwijs \\
\hline \multirow[t]{2}{*}{ Vaders vader } & Geen hoger onderwijs & 61 & 39 \\
\hline & Hoger onderwijs & 33 & 67 \\
\hline \multicolumn{4}{|l|}{ Odds ratio: 3,19} \\
\hline \multicolumn{4}{|c|}{ Correlatie (opleidingsniveau): 0,21 } \\
\hline & & \multicolumn{2}{|c|}{ Kind } \\
\hline & & Geen hoger onderwijs & Hoger onderwijs \\
\hline \multirow[t]{2}{*}{ Moeders vader } & Geen hoger onderwijs & 61 & 39 \\
\hline & Hoger onderwijs & 40 & 60 \\
\hline \multicolumn{4}{|l|}{ Odds ratio: 2,39} \\
\hline \multicolumn{4}{|c|}{ Correlatie (opleidingsniveau): 0,20 } \\
\hline
\end{tabular}

Bron: Familie-enquête Nederlandse Bevolking (FNB) 1992-1993, 1998, 2000, 2003 en 2009 
ouders wel hoger onderwijs hebben, is er echter geen samenhang tussen het opleidingsniveau van de grootvader en het kleinkind. De odds ratio's zijn dan zo goed als 1 . Deze bevinding verdient bijzondere aandacht. Ze geeft aan dat, in overeenstemming met de gedachtegang van Mare (2011), er een interactie is tussen het opleidingsniveau van de grootouders en de ouders. We vinden voor Nederland in de tweede helft van de twintigste eeuw dat het opleidingsniveau van de grootouders er niet toe doet wanneer het ouderlijk opleidingsniveau hoog is.

\section{Lineaire regressiemodellen}

In tabel 4 staan de parameters van lineaire regressiemodellen waarbij het opleidingsniveau van individuen wordt verklaard door dat van hun ouders en grootouders. Omdat we de beschikking hebben over de gegevens van beide ouders en alle vier de grootouders, zijn maar liefst twaalf modellen geschat. We hebben dat niet alleen op het totale bestand gedaan, maar ook voor mannen en vrouwen afzonderlijk en voor het oudere en jongere geboortecohort apart.

Eerst het totaalbeeld. De parameters leren dat in modellen met één onafhankelijke variabele het opleidingsniveau van de vader (M1), vaders vader (M2), vaders moeder (M4), moeder (M6), moeders vader (M7) en

Tabel 3 Samenhang tussen opleiding grootouders en kind naar opleiding ouders (rijpercentages)

\begin{tabular}{|c|c|c|c|c|c|}
\hline & & \multicolumn{4}{|c|}{ Vader } \\
\hline & & \multicolumn{2}{|c|}{ Geen hoger onderwijs } & \multicolumn{2}{|c|}{ Hoger onderwijs } \\
\hline & & \multicolumn{2}{|c|}{ Kind } & \multicolumn{2}{|c|}{ Kind } \\
\hline & & $\begin{array}{c}\text { Geen hoger } \\
\text { onderwijs }\end{array}$ & $\begin{array}{c}\text { Hoger } \\
\text { onderwijs }\end{array}$ & $\begin{array}{c}\text { Geen hoger } \\
\text { onderwijs }\end{array}$ & $\begin{array}{c}\text { Hoger } \\
\text { onderwijs }\end{array}$ \\
\hline \multirow[t]{2}{*}{ Vaders vader } & $\begin{array}{r}\text { Geen hoger } \\
\text { onderwijs }\end{array}$ & 70 & 30 & 31 & 69 \\
\hline & Hoger onderwijs & 53 & 47 & 28 & 72 \\
\hline \multicolumn{6}{|c|}{ Odds ratio's: 2,08 en 1,12} \\
\hline \multicolumn{6}{|c|}{ Partiële correlatie (opleidingsniveau): 0,06} \\
\hline & & \multicolumn{4}{|c|}{ Moeder } \\
\hline & & \multicolumn{2}{|c|}{ Geen hoger onderwijs } & \multicolumn{2}{|c|}{ Hoger onderwijs } \\
\hline & & \multicolumn{2}{|c|}{ Kind } & \multicolumn{2}{|c|}{ Kind } \\
\hline & & $\begin{array}{c}\text { Geen hoger } \\
\text { onderwijs }\end{array}$ & $\begin{array}{c}\text { Hoger } \\
\text { onderwijs }\end{array}$ & $\begin{array}{c}\text { Geen hoger } \\
\text { onderwijs }\end{array}$ & $\begin{array}{c}\text { Hoger } \\
\text { onderwijs }\end{array}$ \\
\hline \multirow[t]{2}{*}{ Moeders vader } & $\begin{array}{r}\text { Geen hoger } \\
\text { onderwijs }\end{array}$ & 65 & 35 & 29 & 71 \\
\hline & Hoger onderwijs & 54 & 46 & 28 & 72 \\
\hline \multicolumn{6}{|c|}{ Odds ratio's: 1,61 en 1,02} \\
\hline \multicolumn{6}{|c|}{ Partiële correlatie (opleidingsniveau): 0,07} \\
\hline
\end{tabular}

Bron: Familie-enquête Nederlandse Bevolking (FNB) 1992-1993, 1998, 2000, 2003 en 2009 


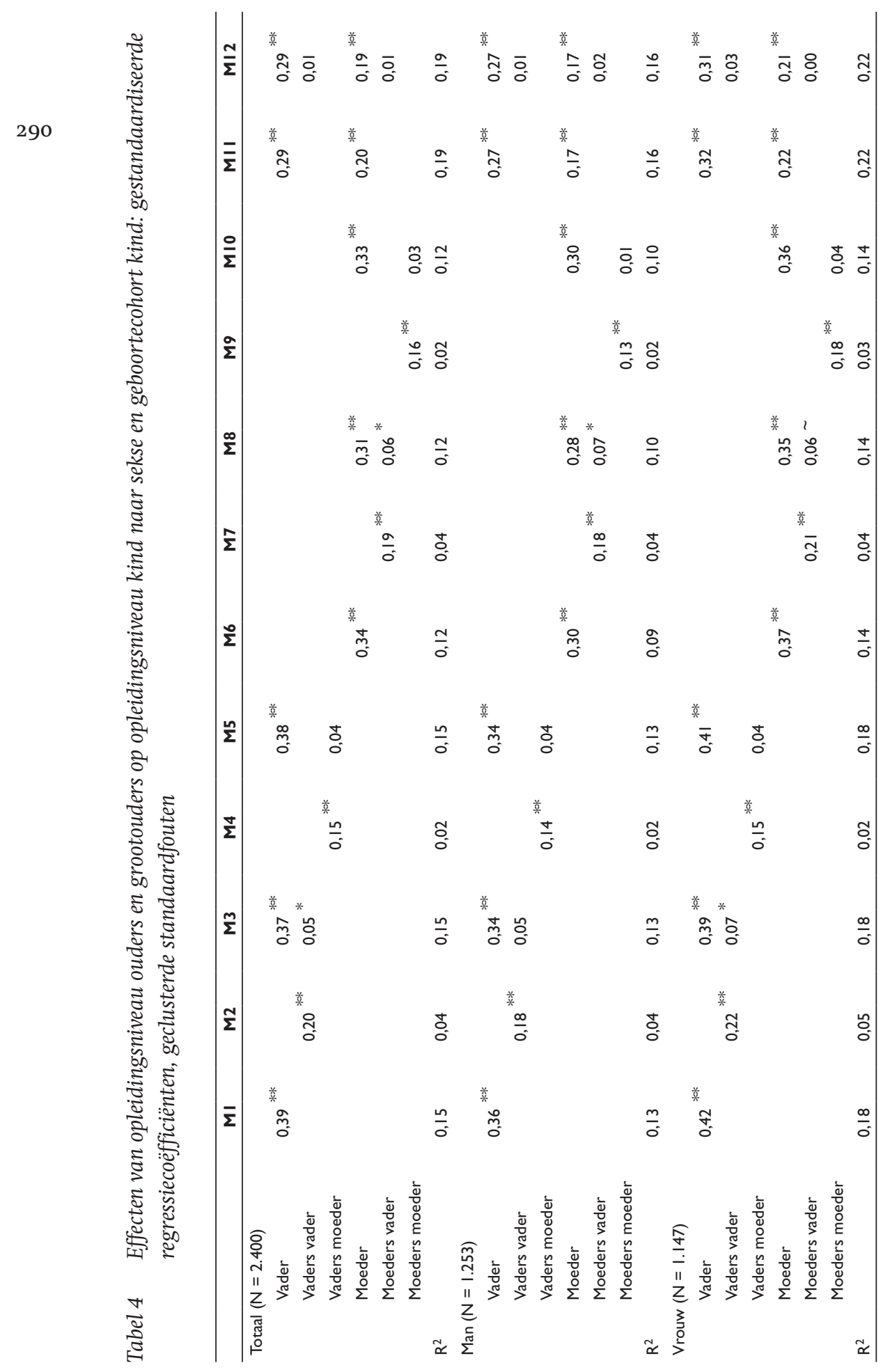




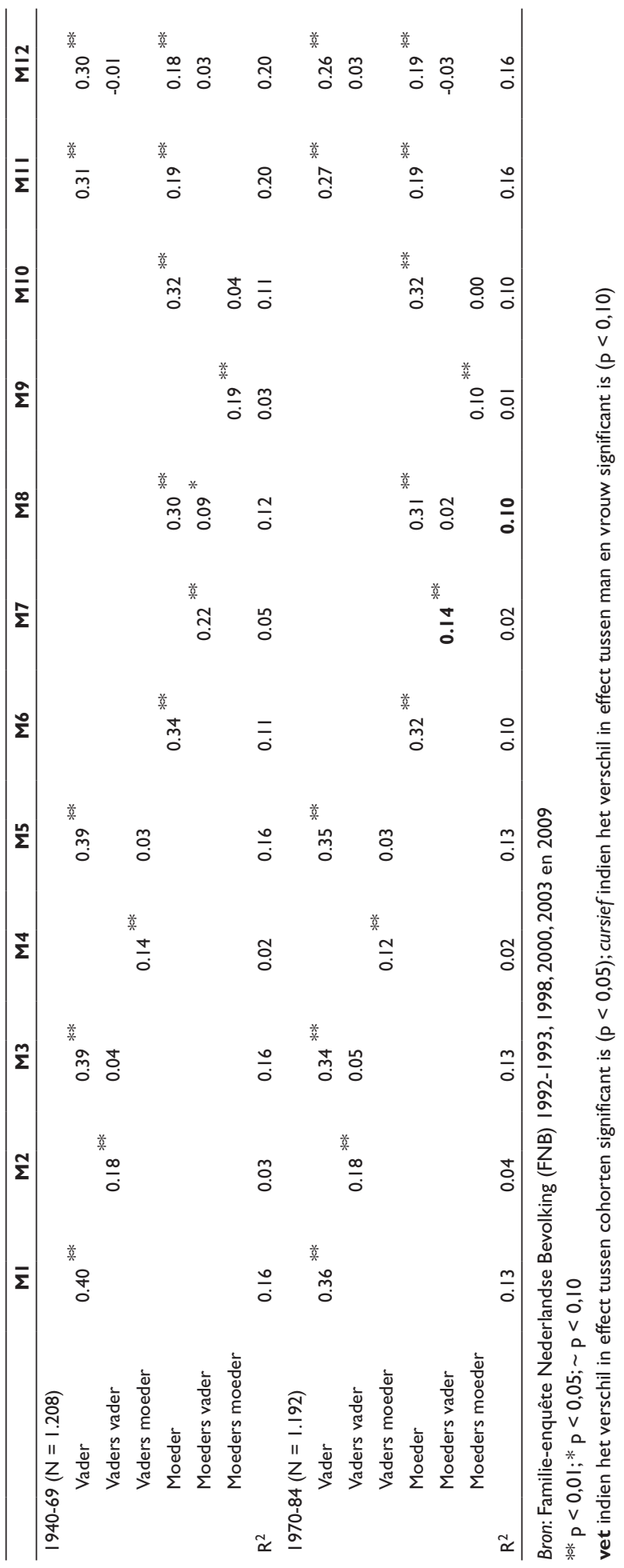


moeders moeder (M9) allemaal een positief significant effect hebben op het opleidingsniveau van het kind. Wanneer we twee onafhankelijke variabelen tegelijkertijd opnemen, één betrekkend hebbend op de eerste generatie en één op de tweede, dan blijkt de opleiding van de grootvader, zowel langs de vaderlijke (M3) als moederlijke (M8) lijn rechtstreeks gevolgen te hebben voor de opleiding van hun kleinkind. De invloed van het niveau van de grootmoeders is geheel indirect. Na controle voor het opleidingsniveau van de vader (M5) of moeder (M10) is het effect van grootmoeders opleiding niet meer significant. De driegeneratieshypothese kunnen we dus alleen bevestigen voor grootvaders (vaders vader en vaders moeder).

Wanneer we vervolgens een model schatten met vier onafhankelijke variabelen, te weten vaders opleiding, vaders vaders opleiding, moeders opleiding en moeders vaders opleiding (M12), dan is alleen de opleiding van beide ouders significant en valt alsnog het effect van de opleiding van beide grootvaders weg. Dit duidt erop dat de invloed van de grootouders indirect is zodra er rekening mee wordt gehouden dat er een samenhang is tussen het opleidingsniveau van beide ouders. De invloed van het opleidingsniveau van de vader op het opleidingsniveau van het kind is overigens groter dan dat van de moeder (M11).

Verschillen tussen mannen en vrouwen zijn er nauwelijks. We constateren weliswaar dat de invloed van het opleidingsniveau van vaders vader op dat van mannen niet significant is (M3), maar het verschil in effect tussen mannen en vrouwen is niet significant. Het enige verschil in effect wordt gevonden voor de invloed van vaders opleiding in M5. Dit effect is groter voor vrouwen $(0,41)$ dan voor mannen $(0,34)$. Ook zijn er bijna geen verschillen tussen beide geboortecohorten. Wel blijkt de invloed van het opleidingsniveau van de grootouders langs de moederlijke lijn kleiner voor leden van het jongere geboortecohort (M7 en M9). Deze bevinding geeft aan dat de hypothese die stelt dat het directe effect van het opleidingsniveau van de eerste op de derde generatie in het latere cohort groter is, niet opgaat.

Hoewel de invloed van de grootouders op hun kleinkinderen gering is boven op wat de ouders voor de opleiding van hun kinderen betekenen, loont het de moeite om omstandigheden aan te duiden waar driegeneratie-effecten mogelijkerwijs het grootst zijn. Net zoals bij het bereiken van een hoge opleiding door kinderen een hoge opleiding van de moeder een lage opleiding van de vader compenseert (Kraaykamp, 2000; Korupp, Ganzeboom \& Van der Lippe, 2002), zo kunnen grootouders met een hoge opleiding hun kleinkinderen wellicht verder helpen in hun onderwijsloopbaan wanneer ouders door hun lage opleiding daartoe minder in staat zijn. Om deze interactiehypothese te onderzoeken, schatten we in tabel 5 drie modellen met interacties tussen de opleiding 
van de grootouders en de ouders (M3', M8', M12'). De resultaten laten in alle gevallen een negatieve interactieterm zien, ook al is die tussen vaders vader en vader niet altijd significant. Dit komt erop neer dat het effect van de opleiding van de grootouders op die van hun kleinkind geringer is, naarmate de opleiding van de ouders hoger is. Zo geeft het totaalbeeld voor M8' aan dat het effect van de opleiding van moeders vader op de opleiding van een kind met een gemiddeld opgeleide moeder 0,10 is, terwijl dit effect $0,10-0,06=0,04$ bedraagt voor een kind met een moeder die een standaarddeviatie hoger dan gemiddeld is opgeleid. De bevindingen van de multipele regressiemodellen komen overeen met de resultaten uit tabel 3 en bevestigen onze hypothese.

\section{Hoeveel meetfouten?}

Kelley (1973) wees op de mogelijkheid van vertekening van effecten als gevolg van meetfouten wanneer modellen van drie generaties worden geschat. Zijn argument is dat fouten in de meting van het opleidingsniveau van de ouders doorwerken in de meting van het opleidingsniveau van de grootouders, waardoor het directe effect van het opleidingsniveau van de grootouders op dat van hun kleinkinderen groter lijkt dan het zou zijn. Hier houden we staande dat de opleiding van de ouders (de primaire respondenten en hun ondervraagde partner) de minste meetfouten bevat, terwijl de meting van de opleiding van de eerste en derde generatie (in gelijke mate) aan meer fouten onderhevig is. Dat in ons geval de ondervraagden tot de tweede generatie behoren, is een voordeel van onze onderzoeksopzet. Terwijl in de eerste onderzoeksfase (Mukherjee, 1954) volwassen kinderen (derde generatie) rapporteren over de opleiding van hun (groot-)ouders, zijn hier respondenten van de tweede generatie bevraagd over hun ouders en kinderen.

Gezien de opzet van de FNB, zouden we, als we over voldoende aantallen ondervraagden hadden beschikt, het opleidingspeil van de eerste generatie zoals gerapporteerd door de tweede generatie in onze regressiemodellen kunnen vervangen door een meting van het opleidingsniveau zoals opgegeven door de eerste generatie zelf. Op vergelijkbare wijze konden we dan het opleidingsniveau van de derde generatie vaststellen door hen er zelf naar te vragen in plaats van dit te laten rapporteren door de tweede generatie. Er is immers een schriftelijke vragenlijst verstuurd aan een van de ouders en een volwassen kind van de primaire respondenten en hun partner. Echter, in de meeste gevallen waren de grootouders al overleden toen het kleinkind volwassen was, of andersom, als een van de grootouders de vragenlijst terugzond, waren de kleinkinderen vaak nog te klein om aan het onderzoek mee te doen. Aan het schatten van dergelijke modellen wagen we ons hier daarom niet. De kwestie 
Tabel 5 Effecten van opleidingsniveau ouders en grootouders op opleidingsniveau kind naar sekse en geboortecohort kind, inclusief interacties: gestandaardiseerde regressiecoëfficiënten, geclusterde standaardfouten

\begin{tabular}{|c|c|c|c|c|c|c|c|}
\hline & & \multicolumn{2}{|c|}{ M3' } & \multicolumn{2}{|c|}{ M8' } & \multicolumn{2}{|c|}{ MI2' } \\
\hline \multicolumn{2}{|c|}{ Totaal $(\mathrm{N}=2.400)$} & & & & & & \\
\hline & Vader & 0,36 & *** & & & 0,28 & *** \\
\hline & Vaders vader & 0,08 & *** & & & 0,04 & \\
\hline & Vaders vader $*$ vader & $-0,04$ & $\sim$ & & & $-0,03$ & \\
\hline & Moeder & & & 0,32 & $* *$ & 0,20 & $* *$ \\
\hline & Moeders vader & & & 0,10 & $* *$ & 0,04 & \\
\hline & Moeders vader $*$ moeder & & & $-0,06$ & $* *$ & $-0,06$ & $* *$ \\
\hline $\mathrm{R}^{2}$ & & 0,15 & & 0,12 & & 0,19 & \\
\hline \multicolumn{8}{|c|}{$\operatorname{Man}(\mathrm{N}=1.253)$} \\
\hline & Vader & 0,34 & *** & & & 0,27 & $* *$ \\
\hline & Vaders vader & 0,08 & $*$ & & & 0,03 & \\
\hline & Vaders vader $*$ vader & $-0,04$ & & & & $-0,03$ & \\
\hline & Moeder & & & 0,29 & $* *$ & 0,18 & $* *$ \\
\hline & Moeders vader & & & 0,11 & $* *$ & 0,06 & \\
\hline & Moeders vader $*$ moeder & & & $-0,08$ & $* *$ & $-0,07$ & ** \\
\hline $\mathrm{R}^{2}$ & & 0,13 & & 0,11 & & 0,16 & \\
\hline \multicolumn{8}{|c|}{ Vrouw $(\mathrm{N}=1.147)$} \\
\hline & Vader & 0,39 & ** & & & 0,30 & ** \\
\hline & Vaders vader & 0,10 & ** & & & 0,06 & \\
\hline & Vaders vader $*$ vader & $-0,05$ & $\sim$ & & & $-0,05$ & \\
\hline & Moeder & & & 0,35 & $* *$ & 0,22 & *** \\
\hline & Moeders vader & & & 0,09 & * & 0,03 & \\
\hline & Moeders vader $*$ moeder & & & $-0,05$ & $\sim$ & $-0,04$ & \\
\hline $\mathrm{R}^{2}$ & & 0,18 & & 0,15 & & 0,22 & \\
\hline \multicolumn{8}{|c|}{$1940-69(\mathrm{~N}=1.208)$} \\
\hline & Vader & 0,38 & ** & & & 0,30 & $* *$ \\
\hline & Vaders vader & 0,07 & $\sim$ & & & 0,03 & \\
\hline & Vaders vader $*$ vader & $-0,05$ & & & & $-0,05$ & \\
\hline & Moeder & & & 0,31 & $* *$ & 0,20 & **⿰㇇⿰亅⿱丿丶丶 \\
\hline & Moeders vader & & & 0,13 & $* *$ & 0,06 & \\
\hline & Moeders vader $*$ moeder & & & $-0,05$ & $\sim$ & $-0,05$ & $\sim$ \\
\hline $\mathrm{R}^{2}$ & & 0,16 & & 0,12 & & 0,20 & \\
\hline \multicolumn{8}{|c|}{$1970-84(\mathrm{~N}=1.192)$} \\
\hline & Vader & 0,33 & ** & & & 0,26 & ** \\
\hline & Vaders vader & 0,06 & $\sim$ & & & 0,04 & \\
\hline & Vaders vader $*$ vader & $-0,02$ & & & & $-0,01$ & \\
\hline & Moeder & & & 0,31 & $* *$ & 0,19 & ** \\
\hline & Moeders vader & & & 0,05 & & 0,00 & \\
\hline & Moeders vader $*$ moeder & & & $-0,06$ & $*$ & $-0,06$ & $*$ \\
\hline $\mathrm{R}^{2}$ & & 0,13 & & 0,11 & & 0,16 & \\
\hline
\end{tabular}

Bron: Familie-enquête Nederlandse Bevolking (FNB) 1992-1993, 1998, 2000, 2003 en 2009 ** $\mathrm{p}<0,01$ I; $\mathrm{p}<0,05 ; \sim \mathrm{p}<0,10$ 
van de grootte en richting van systematische fouten in de meting van de opleiding van kinderen, ouders en grootouders beschouwen we als een zaak die een afzonderlijk artikel verdient.

\section{Conclusie en discussie}

Duncan (Blau \& Duncan, 1967) en andere exponenten van de tweede fase van onderzoek naar sociale stratificatie en mobiliteit hadden het alleen over twee generaties en dan alleen over vaders. In dit artikel hadden wij het over vader en moeder en hadden we het over drie generaties en dan niet alleen over vaders vader, maar ook over moeders vader en over beide grootmoeders. Naast de centrale hypothese dat hoger opgeleide grootouders rechtstreeks een hogere opleiding voor hun kleinkinderen bewerkstelligen, formuleerden we in dit artikel twee andere, daaraan gerelateerde hypothesen. Volgens de ene hypothese heeft de opleiding van de moeder, naast die van de vader, een positief effect op de opleiding van het kind, waarbij het effect van moeders opleiding kleiner is dan dat van vaders opleiding. Volgens de andere hangt de opleiding van grootvaders en hun zonen samen en heeft een hogere opleiding van grootvaders als gevolg dat hun zonen een vrouw met een hogere opleiding huwen.

Uit de verrichte empirische analyse voor hedendaags Nederland blijkt dat het opleidingsniveau van de grootouders positief samenhangt met dat van hun kleinkinderen. Alleen in het geval van grootvaders is dit effect, in causale zin, ook direct. De opleiding van de grootvader, zowel langs de vaderlijke als moederlijke lijn, heeft een rechtstreekse invloed op de opleiding van het kleinkind. Na controle voor de opleiding van een van beide ouders blijft zo'n derde tot een kwart van het totale effect van de opleiding van de grootvader bestaan. De invloed van de opleiding van de grootmoeder is geheel indirect. Als wordt gecontroleerd voor de opleiding van de vader of de moeder, dan is het effect van de opleiding van de grootmoeder niet significant. $\mathrm{Er}$ is in Nederland dus enige steun voor de driegeneratieshypothese.

Wanneer we echter de intermediërende rol van beide ouders tegelijkertijd in ogenschouw nemen, dan blijkt alleen het opleidingsniveau van de ouders bepalend te zijn en valt het effect van het opleidingsniveau van de vader van beide ouders alsnog weg. Dit duidt erop dat de invloed van de grootouders indirect verloopt zodra rekening wordt gehouden met het feit dat er een samenhang is tussen het opleidingsniveau van beide ouders. Zo vormen moeders dus een belangrijke tussenschakel van vaders vader naar het kleinkind. De invloed van het opleidingsniveau van de vader op het opleidingsniveau van het kind is, zoals verwacht, groter dan dat van de moeder. 
Verschillen tussen mannen en vrouwen zijn er nauwelijks in de effecten van de opleiding van de (groot)ouders op die van hun (klein)kinderen. Evenmin zijn er wezenlijke verschillen tussen beide onderzochte geboortecohorten geconstateerd. Er is dus geen steun voor de hypothese dat het directe effect van het opleidingsniveau van de grootouders op dat van hun kleinkinderen in de loop van de tijd is toegenomen. Wel vonden we een interactie tussen de opleiding van de grootvaders en de ouders. De interpretatie luidt dat het effect van de opleiding van de grootvaders op die van hun kleinkinderen geringer is, naarmate de opleiding van de ouders hoger is. Alleen kinderen van laagopgeleide ouders blijken profijt te hebben van een hoogopgeleide grootvader; kinderen van hoogopgeleide ouders ondervinden hier geen voordeel van. Deze bevinding steunt de hypothese van Mare (2011) die stelt dat de opleiding van de ouders het effect van de opleiding van de grootouders op die van hun kleinkinderen niet alleen medieert, maar ook modereert.

Ondanks het beantwoorden van een aantal nieuwe vragen in dit artikel, zijn andere blijven liggen. Een vanzelfsprekende vervolgvraag is die naar de verklaring van het gevonden grootouderlijke opleidingseffect. Is er bijvoorbeeld sprake van een directe overdracht van culturele hulpbronnen tussen grootouders en kleinkinderen? En is de mogelijk verklarende rol van culturele hulpbronnen in de loop van de tijd belangrijker geworden vanwege het feit dat door de toegenomen levensverwachting van individuen de overlap in levens tussen grootouders en kleinkinderen groter is geworden? Dergelijke vragen horen thuis in vervolgonderzoek. Op het methodologische vlak ligt nog de kwestie van meetfouten. We achten het nog steeds zinvol driegeneratiesmodellen te ontwikkelen met dubbele metingen. Dan pas wordt duidelijk of de in dit artikel gevonden resultaten standhouden.

Tot slot. Hoewel Mare (2011) opriep de tweegeneratiesmodellen voor statusverwerving van Duncan (Blau \& Duncan, 1967) te vervangen door modellen voor meer dan twee generaties, hebben we hier aangetoond dat vragen over drie generaties al aan bod kwamen in de eerste fase van het onderzoek naar sociale stratificatie en mobiliteit. Ook bleek dat een verschuiving van Duncans vraag over één ouder (de vader) naar de beide ouders (de vader en de moeder) van een persoon wellicht meer op de plaats is dan een verschuiving van tweegeneratiesvragen naar vragen over drie (of nog meer) generaties. Onze resultaten duiden erop dat een rechtstreeks lijkende invloed van de opleiding van de vader van iemands vader, indirect wordt als men rekening houdt met het effect van de opleiding van iemands moeder en met de invloed van de opleiding van vaders vader bij de keuze voor een hoger opgeleide partner. 


\section{Noten}

1. Correspondentie-adres: Sectie Sociologie, Radboud Universiteit Nijmegen, Postbus 9104, 6500 HE Nijmegen. E-mail: m.wolbers@maw.ru.nl.

2. In het Engels wordt de term generations gebruikt om de opeenvolgende fasen in het onderzoek naar stratificatie en mobilitet aan te duiden. Dat doen we hier niet, om verwarring te voorkomen met de generaties uit een voortplantingsreeks (grootouders, ouders, [klein]kinderen), waarover de vragen van dit artikel gaan.

3. Voor een gedetailleerde beschrijving van de FNB verwijzen we naar http://www. ru.nl/sociologie/onderzoek/onderzoeksprojecten/familie-enquete/achtergrond_ van_de.

4. Om die reden hebben we alleen primaire respondenten geselecteerd met een partner van het andere geslacht die op het moment van ondervraging zich in hun eerste huwelijk of samenwoonrelatie bevonden zodat de onderzochte kinderen hun gezamenlijke, biologische nakomelingen betreffen.

\section{Literatuur}

Berent, J. (1954). Social mobility and marriage: Study of trends in England and Wales. In D.V. Glass (ed.), Social mobility in Britain (pp. 321338). London: Routledge \& Kegan Paul.

Blau, P.M. \& Duncan, O.D. (1967). The American occupational structure. New York: Wiley.

Blossfeld, H.-P. \& Mayer, K.-U. (1988). Labour market segmentation in the Federal Republic of Germany. European Sociological Review, 4, 123-140.

Bourdieu, P. (1980). La distinction. Paris: Minuit.

Breen, R. \& Luijkx, R. (2004). Social mobility in Europe between 1970 and 2000. In R. Breen (ed.), Social mobility in Europe (pp. 37-75). Oxford: Oxford University Press.

Breen, L., Luijkx, R., Müller, W. \& Pollak, R. (2009). Nonpersistent inequality in educational attainment: Evidence from eight European countries. American Journal of Sociology, 114, 1475-1521.

Chan, T.W. \& Boliver, V. (2013). The grandparents effect in social mobility: Evidence from British birth cohort studies. Forthcoming in American Sociological Review, 78.

Collins, R., (1981). The credential society. New York: Academic Press.

Engbersen, G. (1990). Publieke bijstandsgeheimen. Het ontstaan van een onderklasse in Nederland. Leiden/Antwerpen: Stenfert Kroese.

Erikson, R. \& Goldthorpe, J.H. (1992). The constant flux. A study of class mobility in industrial societies. Oxford: Clarendon Press.

Featherman, D.L. \& Hauser, R.M. (1978). Opportunity and change. New York: Academic Press.

Ganzeboom, H.B.G., Treiman, D.J. \& Ultee, W.C. (1991). Comparative intergenerational stratification research: Three generations and beyond. Annual Review of Sociology, 17, 277-302. 
Glass, D.V. (ed.) (1954). Social mobility in Britain. London: Routledge \& Kegan Paul.

Goldthorpe, J.H. (1980). Social mobility and class structure in modern Britain. Oxford: Clarendon Presss.

Graaf, N.-D., Smeenk, W., Ultee, W. \& Timm, A. (2003). The when and whom of first marriage in the Netherlands. In H.-P. Blossfeld \& A. Timm (eds.). Who marries whom? Educational systems as marriage markets in modern societies (pp. 79-111). Dordrecht: Kluwer.

Halsey, A.H., Heath, A.F. \& Ridge, J.M. (1980). Origins and destinations. Family, class, and education in modern Britain. Oxford: Clarendon Press.

Jencks, C., \& Peterson, P.E. (eds.) (1991). The urban underclass. Washington: Brookings.

Kelley, J. (1973). Causal chain models for the socio-economic career. American Sociological Review, 38, 481-493.

Kraaykamp, G. (2000). Ouderlijk gezin en schoolsucces. Een verklaring met demografische, culturele en sociale aspecten. Tijdschrift voor Onderwijsresearch, 25, 179-194.

Korupp, S.E., Ganzeboom, H.B.G. \& Lippe, T. van der (2002). Do mothers matter? A comparison of models of the influence of mother's and father's educational and occupational status on children's educational attainment. Quality \& Quantity, 36, 17-42.

Lipset, S.M., \& Bendix, R. (1959). Social mobility in industrial society. Berkeley: University of California Press.

Lundberg, F. (1968). The rich and the superrich. New York: Bantam.

Mare, R.D. (2011). A multigenerational view of inequality. Demography, 48, 1-23.

Mukherjee, R. (1954). A study of mobility between three generations. In D.V. Glass (eds.), Social mobility in Britain (pp. 266-290). London: Routledge \& Kegan Paul.

Schumpeter, J. (1927). Die sozialen Klassen im ethnisch homogenen Milieu. Archiv für Sozialwissenschaften und Sozialpolitik, 57, 1-67; Engelse vertaling in J. Schumpeter (1951), Imperialism and social classes, two essays. Cleveland: The World Publishing Company.

Sorokin, P. (1927). Social mobility. New York: Harper.

Svalastoga, K. (1959). Prestige, class and mobility. Copenhagen: Gyldendal.

Treiman, D.J. \& Ganzeboom, H.B.G. (2000). The fourth generation of comparative stratification research. In S. Quah \& A. Sales (eds.), The international handbook of sociology (pp. 123-150). Thousand Oaks, CA: Sage.

Tulder, J.J.M. van (1962). De beroepsmobiliteit in Nederland van 1919 tot 1954. Leiden: Stenfert Kroese.

Ultee, W., Arts, W. \& Flap, D. (2003). Sociologie. Vragen, uitspraken, bevindingen. Derde, herziene, druk. Groningen: Wolters-Noordhoff.

Ultee, W. \& Luijkx, R. (1990). Educational heterogamy and father-to-son 
occupational mobility in 23 industrial nations: General societal openness or compensatory strategies of reproduction? European Sociological Review, 6, 125-149.

Vries, J. de \& Graaf, P.M. de (2008). The reliability of family background effects on status attainment: Multiple informant models. Quality and Quantity, 42, 203-234.

\section{Gebruikte gegevens}

Ganzeboom, H.B.G. \& Ultee, W.C. (1993). Familie-enquête Nederlandse Bevolking 1992-1993 [dataset]. Sectie Sociologie, Radboud Universiteit Nijmegen [producent]. Den Haag: DANS [distributeur].

Graaf, N.-D. de, Graaf, P.M. de, Kraaykamp, G. \& Ultee, W.C. (1998). Familieenquête Nederlandse Bevolking 1998 [dataset]. Sectie Sociologie, Radboud Universiteit Nijmegen [producent]. Den Haag: DANS [distributeur].

Graaf, N.-D. de, Graaf, P.M. de, Kraaykamp, G. \& Ultee, W.C. (2000). Familieenquête Nederlandse Bevolking 2000 [dataset]. Sectie Sociologie, Radboud Universiteit Nijmegen [producent]. Den Haag: DANS [distributeur].

Graaf, N.-D. de, Graaf, P.M. de, Kraaykamp, G. \& Ultee, W.C. (2003). Familieenquête Nederlandse Bevolking 2003 [dataset]. Sectie Sociologie, Radboud Universiteit Nijmegen [producent]. Den Haag: DANS [distributeur].

Kraaykamp, G., Ruiter, S. \& Wolbers, M.H.J. (2009). Familie-enquête Nederlandse Bevolking 2009 [dataset]. Sectie Sociologie, Radboud Universiteit Nijmegen [producent]. Den Haag: DANS [distributeur]. 